\title{
Reusable face mask for the knitted fabric with finishes treatment
}

\begin{abstract}
This will surgical mask beneficially for the user of village people and communities, at home and at health care facilities in areas. Experimental work was done to study the reusable face masks knitted fabric of the thickness, Pore size analysis, finishing characteristics performance and comfort \& moisture management properties. According to the analysis, it has observed that all the parameters are significantly affected. I have some tested above the surface and I found that the results are good face masks. It will help to prevent covid 2019 virus infection. It is able to anti-dust pollution, washable \& reusable product. It is faster sweat absorption and provides disease protection, relief from bad odours and more for ultimate best performance by face masks. It will help to catch the bacteria shed in liquid droplets and aerosols from the wearer's mouth and nose. This is a reusable surgical mask. This will use mask reusable fifteen times and very low cost this product. Now present-day surgical mask available in the market only one time used. Now present situation, it has not easily available surgical mask in the small town or village area. Now present-day available some mask inside market did not follow any technical specification standard. Now the present day has we main motif for the easily available good quality mask for the village \& small town. It will be easily available for the low cost \& reusable surgical mask.
\end{abstract}

Keywords: polyester yarn, face masks knitted, Antimicrobial and moisture management finish
Volume 6 Issue 2 - 2020

\begin{abstract}
Ramratan,' Anupam Kumar, ${ }^{2}$ Rohit Kumar ${ }^{3}$
'Assistant Professor, Department of Textile Engineering, Giani Zail Singh Campus College of Engineering and Technology, Maharaja Ranjit Singh Punjab Technical University, India 2Professor, Department of Textile Engineering, Giani Zail Singh Campus College of Engineering and Technology, Maharaja Ranjit Singh Punjab Technical University, India

${ }^{3}$ Research Scholar, Department of Textile Engineering, Giani Zail Singh Campus College of Engineering and Technology, Maharaja Ranjit Singh Punjab Technical University, India
\end{abstract}

\section{Correspondence: Ramratan, Department of Textile} Engineering, Giani Zail Singh Campus College of Engineering and Technology, Maharaja Ranjit Singh Punjab Technical University, Bathinda-15I00I, Punjab, India,

Email ramratan333@gmail.com, anup28298@yahoo.com

Received: April 03, 2020 | Published: April 30, 2020

\section{Introduction}

A surgical mask is a loose-fitting, this device that creates a physical barrier between the mouth and nose of the wearer and potential contaminants in the immediate environment. ${ }^{1}$ The Centers for Disease Control and Prevention (CDC) does not recommend that people who are well wearing a face mask to protect themselves from respiratory diseases, including corona virus (COVID-19). Surgical masks are made in different thicknesses and with different ability to protect you from contact with liquids. ${ }^{2}$ These properties may also affect how easily you can breathe through the face mask and how well the surgical mask protects you. If worn properly, a surgical mask is meant to help block large-particle droplets, splashes, sprays, or splatter that may contain germs (viruses and bacteria), keeping it from reaching your mouth and nose. Surgical masks may also help reduce exposure of your saliva and respiratory secretions to others. ${ }^{3}$ Simple surgical masks protect wearers from being splashed in the mouth with body fluids and prevent transmission of body fluids from the wearer to others, e.g. the patient. They also remind wearers not to touch their mouth or nose, which could otherwise transfer viruses and bacteria after having touched a contaminated surface (fomite).$^{4}$ They can also reduce the spread of the infectious liquid. Surgical masks are popularly worn by the general public in East Asian countries to reduce the chance of spreading airborne diseases. To reduce the chance of spreading airborne diseases and to prevent the breathing in of airborne dust particles created by air pollution. Additionally, surgical masks have become a fashion statement, particularly in contemporary East Asian culture bolstered by its popularity in Japanese and Korean pop culture which have a big impact on East Asian youth culture. ${ }^{5}$ Doust and Lyon author observed the role of surgical face masks is to prevent respiratory tract-based infections. They also found that the surgical face masks with two layers provide better protection to the wearer as compared to the single-layer face masks. ${ }^{6}$ They also found that speaking with a surgical face mask in an ordinary conversation for $5 \mathrm{~min}$ release relatively few bacteria from the mouth to a distance of only 1 to $2 \mathrm{ft}$. In case of without surgical face masks, for $5 \mathrm{~min}$, the liberation of bacteria from the mouth is quite high. And the liberated bacteria are found even to as distance more than $3 \mathrm{ft} .{ }^{7}$ Surgical face masks not only provide a barrier for airborne organisms, but it also protects the wearer against splashing of blood and other body fluids. ${ }^{8}$

Moisture transport in textile has been an important area of research for many decades. In these conditions, moisture vapor transmission and moisture accumulation under clothing determine the comfort of masks fabric. ${ }^{9}$ Globalization has added competition at the highest level in making an apparel product more sustainable, fashionable and customer focused. This has been possible with textile chemical finishing applications. Hence, finishing is the heart of textile processing and it imparts functional and protective features like anti-microbial, moisture management and many more properties. It accomplishes the result of making the fiber more absorbent (hydrophilic). Antimicrobial finished textile lowers down the psychological discomfort associated with foul odour arising out of microbial growth and by fungi causing skin infections. This growth of microbes can be stopped by reducing cross-interaction in the textile material by applying antimicrobial finish. ${ }^{10}$

I have the main purpose to provide a new concept with a reusable face mask. This will surgical mask beneficially for the user of village people and communities, at home and at health care facilities in areas. It will help to prevent covid 2019 virus infection. It is able to antidust pollution, washable \& reusable product. The main purpose of a Moisture management finish is to develop the ability of textiles to absorb humidity from the skin, transport it to their outer surface and 
release it into the surrounding air. Hence, it is faster sweat absorption and antimicrobial finish will provide disease protection, relief from bad odours and more for ultimate best performance by face masks.

\section{Materials and methods}

\section{Material}

Two different filament yarns used in this study. The polyester filaments are varied in fineness and surface texture. Yarn denier is kept constant $80 \mathrm{D}$ for equivalent fabric properties where number of constitute hexagonal polyester filaments is varied as per Table 1 . The quality parameters of manufactured yarn are mentioned in Table 2.
Table I Characteristics of polyester yarn used

\begin{tabular}{lll}
\hline Properties & Yarn I & Yarn 2 \\
\hline Type & $\begin{array}{l}\text { Micro polyester } \\
\text { filament yarn }\end{array}$ & $\begin{array}{l}\text { Texturized } \\
\text { polyester filament } \\
\text { yarn }\end{array}$ \\
Blend & $100 \%$ & $100 \%$ \\
$\begin{array}{l}\text { Yarn Fineness (Denier) } \\
\begin{array}{l}\text { No. of filaments in cross- } \\
\text { section }\end{array}\end{array}$ & $80 \mathrm{D}$ & $80 \mathrm{D}$ \\
\hline
\end{tabular}

Table 2 Yarn quality parameters

\begin{tabular}{lllll}
\hline Parameters & Breaking force (kgf) & Tenacity (cN/kg) & Elongation (\%) & Unevenness (\%) \\
\hline Micro polyester filament yarn & 0.6132 & 19.692 & 12.15 & 13.42 \\
Texturized polyester filament yarn & 0.6303 & 22.888 & 15.4 & 15.46 \\
\hline
\end{tabular}

The face masks have been made by the fine mesh structure micropolyester knitted fabric and interlock structure polyester knitted fabric. The fabrics were scoured, bleached and made ready for dyeing

Table 3 Functional finishes for the details
(RFD fabrics) and then treated with two different functional finishing (Table 3) \& three -layer surgical mask protocol, show as below (Figure 1) (Figure 2). I have shown in the (Figure 3) three-layer reusable face masks.

\begin{tabular}{llll}
\hline Functional finishes & Chemical characteristics & PH level & lonic nature \\
\hline Eco finish AB I000 antimicrobial finish & Quatarnery ammonium compound & 6 & Cationic \\
Evo Fin PSR Moisture Management finish & Hydrophilic silicone softener & 4.5 & Non-ionic \\
\hline
\end{tabular}

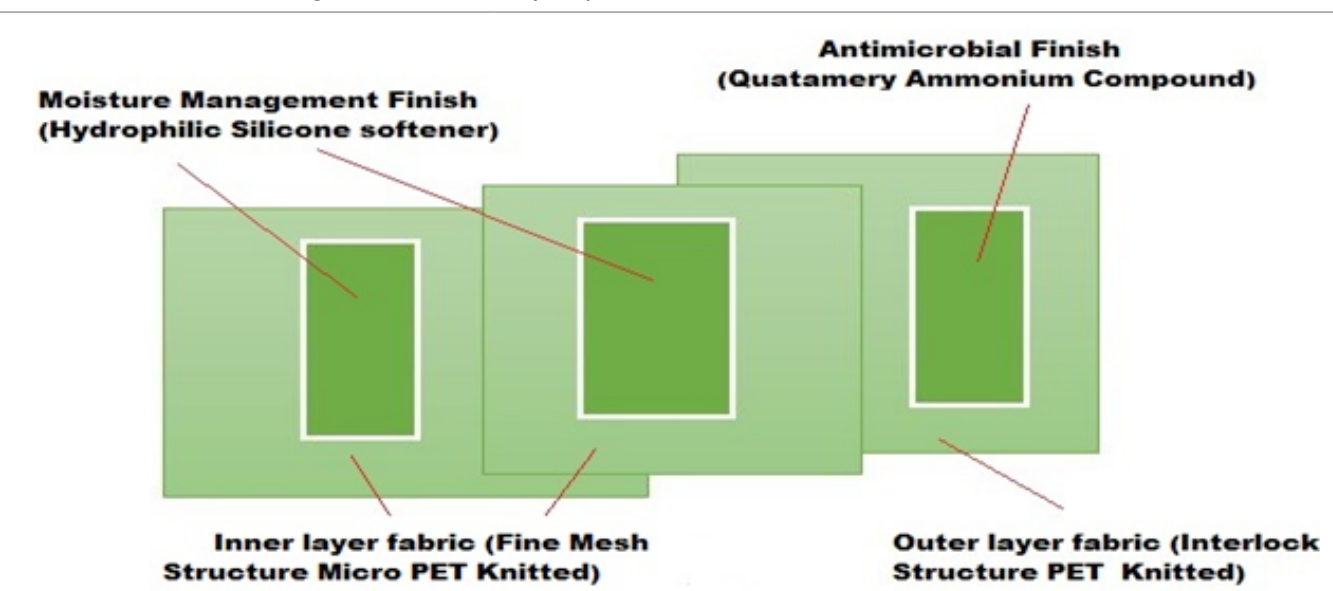

Figure I Three-layer surgical mask protocol.
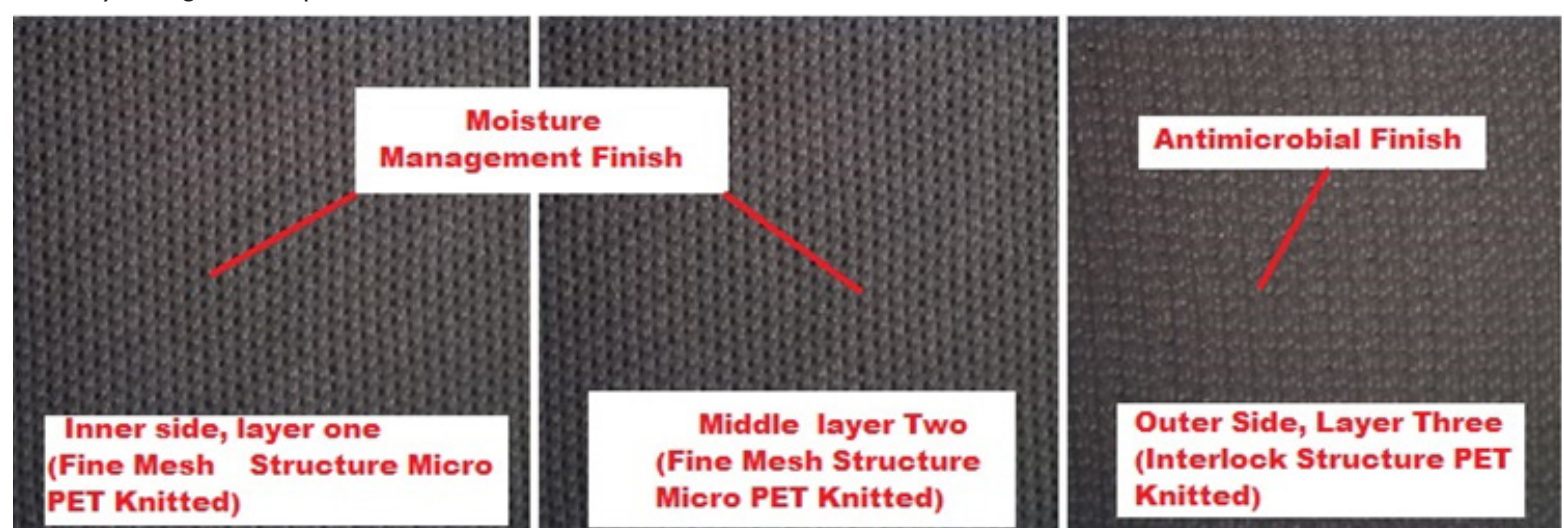

Figure 2 Microscopic view, reusable for the three -layer surgical mask protocol. 


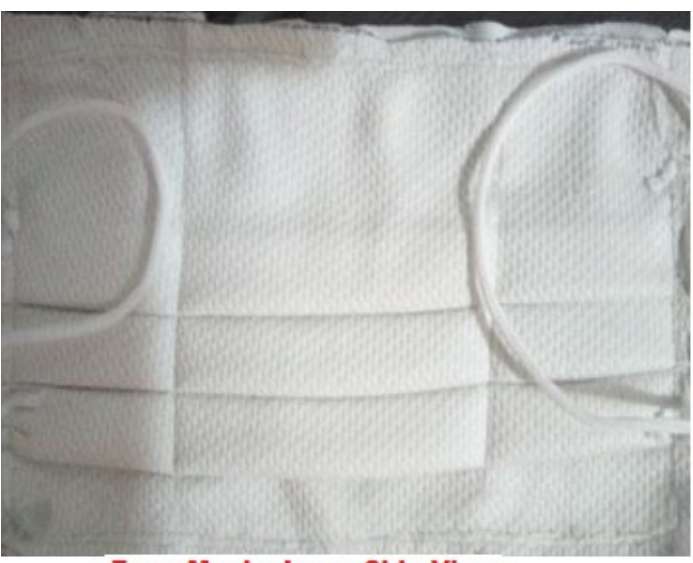

Face Masks Inner Side View

Figure 3 Reusable for the three-layer surgical mask sample image. Methods

Thickness testing: Thickness testing was carried out as per BS EN ISO 9073-2 using the electronic thickness tester at $0.25 \mathrm{KPa}$ pressure. For each sample 30 readings were taken to get the result at $95 \%$ confidence level.

Air permeability testing: The air permeability of a fabric is closely related to the construction characteristics of the yarns and fabrics in which large volumes are occupied by air. The air permeability of a fabric is a measure of how well it allows the passage of air through it and is defined as the volume of air passed in one second through 100 square.mm of the fabric at a pressure difference of $10 \mathrm{~mm}$ of water Air permeability was carried out as per ASTM D737 using FX 3300 air permeability tester. Testing was carried out in a circular test head of diameter 15.07 at test pressure of $98 \mathrm{~Pa}$. The rate of air flow through the fabric was obtained in terms $\mathrm{cm}^{3} / \mathrm{cm}^{2} / \mathrm{s}$.

Capillary flow porometer test: ASTM F-316-03 standard, the PMI capillary flow porometer, a fully automated through pore analysis machine, gives information on bubble point, pore size distribution, mean flow pore size. The capillary flow porometer allows you test samples under compression dry and wet condition.

\section{Evaluation of performance of finished fabric}

Fabric treatment process: The prepared solutions (Quatarnery ammonium compound, Benzotriazole solution, and Modified Polyurethane) were applied on fabrics using pad-dry-cure method. The fabrics were cut into the sizes of $30 \mathrm{~cm} X 30 \mathrm{~cm}$ and were immersed in the solutions and citric acid binder $(1 \%)$ for $5 \mathrm{~min}$. The samples were then passed through a padding mangle, running at a speed of $15 \mathrm{~m} / \mathrm{min}$ with a pressure of $1 \mathrm{kgf} / \mathrm{cm}^{2}$ to remove excess solution. A $100 \%$ wet pick-up was maintained for all of the treatments. After padding, the fabric was air dried and then cured for $2 \mathrm{~min}$ at $140^{\circ} \mathrm{C}$ and again immersed for $5 \mathrm{~min}$ in $2 \mathrm{~g} / \mathrm{l}$ of sodium lauryl sulfate to remove unbound nanoparticles and rinsed with water to remove the soap solution followed by air-drying. ${ }^{11,12}$

Antimicrobial activity: The test was carried as per the method mentioned in ASTM E-2149. Antimicrobial test of Quatarnery ammonium compound treated fabric was carried out with grampositive Staphylococcus aureus and gram-negative Escherichia coli bacterium. Experimenting with bacterium is very crucial, as it is infectious for human beings. The size of samples was $1 \times 1$ sq. inch for the treatment. Quatarnery ammonium compound-treated and

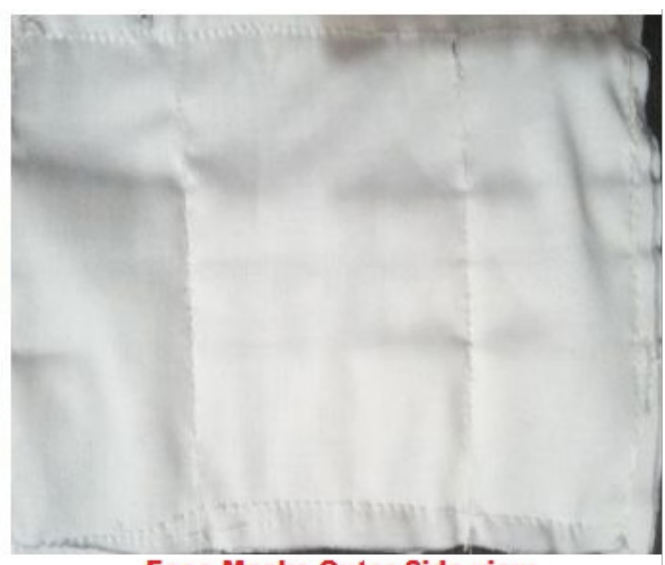

Face Masks Outer Side view

untreated samples were kept separately in two $40 \mathrm{ml}$ conical flasks containing $10 \mathrm{ml}$ of liquid culture (Luria Broth), in which $0.1 \mathrm{ml}$ of microbial culture was inoculated in laminar flow. All the closed flasks stirred with shaker incubator for four hours at 200rpm. The inoculated test cultures with treated and untreated samples were analyzed by UV spectrophotometer for optical density measurement. The percentage reduction in bacterial growth was calculated using the following equation (1).

Percent reduction of bacterial growth $=\frac{(B-A)}{B} \times 100$

Where, A is the optical density of the inoculated test culture containing the treated sample.

$\mathrm{B}$ is the optical density of the inoculated test culture containing the untreated sample.

\section{Vertical wicking}

The vertical wicking test of the fabric was carried out according to standard DIN 53924-strip test method through an apparatus developed in institute lab and the results were measured in terms of wicking height in centimeters.

Procedure: In this test, a strip of fabric was suspended vertically with its lower edge in a reservoir of distilled water. The rate of rise of water through the leading edge was then monitored. To detect the position of the waterline, a dye was added to water. The measured height of rise in a given time was taken as a direct indication of the wick-ability of the test fabric. The sample size is $20 \mathrm{~cm} \times 2.5 \mathrm{~cm}$ and the measurement is recorded 4 times after every $5 \mathrm{~min}$ i.e. at $5 \mathrm{~min}, 10 \mathrm{~min}, 15 \mathrm{~min}$ in the wale's direction.

Bacterial filtration efficiency test: This test method has been specifically designed for measuring bacterial filtration efficiency of face masks, using Staphylococcus aureus as the challenge organism as per standard ASTM F-2101. The use of S. aureus is based on its clinical relevance as a leading cause of nosocomial infections. This test method has been designed to introduce a bacterial aerosol challenge to the test specimens at a flow rate of $28.3 \mathrm{~L} / \mathrm{mm}$. $\left(1 \mathrm{ft}^{3} / \mathrm{min}\right)$.

SEM (scanning electron microscope) and FTIR (Fourier transform infrared spectroscopy): The surface of the coated fabrics was investigated using a SEM XL 30, Philips. To confirm the impregnation of finish on the fabrics, FTIR was recorded at a wave 
number range of $500-4000 \mathrm{~cm}^{-1}$. The characteristic peaks observed in FTIR graph could explain the presence of the functional group from applied finishes on the fabric surface as per show figure below.

Laundering cycle test: Clothing intended for repeated use must be able to be laundered. Thus, it is important to investigate any change in moisture management \& antimicrobial properties that may occur as a result of laundering. The investigation is carried out for samples without finished and laundered 15 times to record changes occurring in moisture management\& antimicrobial property after wash cycle process. The finished fabric samples are washed according to JIS-L 1089.

\section{Results and discussion}

\section{Influence of antimicrobial finishes}

Antimicrobial properties of the samples were tested with Pseudomonas aeruginosa bacterium. It is observed from (Table 4)

Table 4 Antimicrobial activity of PET\& Mirco PET knitted masks fabrics that all the knitted fabric treated with concentrations of Quatarnery ammonium compound is showed uniform improvement in antimicrobial property. This can be also revealed from the SEM images (Figure 4) (Figure 5) at the coating of the fibers of the polyester and micro polyester with a particle size ranging $10 \mathrm{~nm}$. Figure 6 shows the FTIR spectra of the polyester fabrics treated as well as untreated. To confirm the impregnation of finish on the polyester fabric, the fourier transform infrared spectroscopy was recorded at a wave number range of 500-4000 $\mathrm{cm}^{-1}$. There were some characteristic peaks of the functional group which could explain the presence of antimicrobial finish on the polyester fabric. In the case of polyester knitted fabric, the ester $(\mathrm{C}=\mathrm{O})$ bond was observed at $1712 \mathrm{~cm}^{-1}$, while with treated polyester, N-H asymmetric vibration was observed at $3429 \mathrm{~cm}^{-1}$. This peak indicates the presence of antimicrobial finish on knitted polyester sample. ${ }^{13}$

It is finally observed that the antimicrobial properties of polyester, Mirco polyestermask fabric got improved with the Quatarnery ammonium compound antimicrobial finish.

\begin{tabular}{llll}
\hline Fabric sample & & $\begin{array}{l}\text { Optical density of microbial } \\
\text { liquid culture with sample }\end{array}$ & $\begin{array}{l}\text { Reduction of bacterial } \\
\text { growth (\%) }\end{array}$ \\
\hline \multirow{2}{*}{ Micro polyester } & Untreated & 0.117 & No reaction \\
& Treated & 0.068 & 41.88 \\
Polyester & Untreated & 0.119 & No reaction \\
& Treated & 0.066 & 44.53 \\
\hline
\end{tabular}

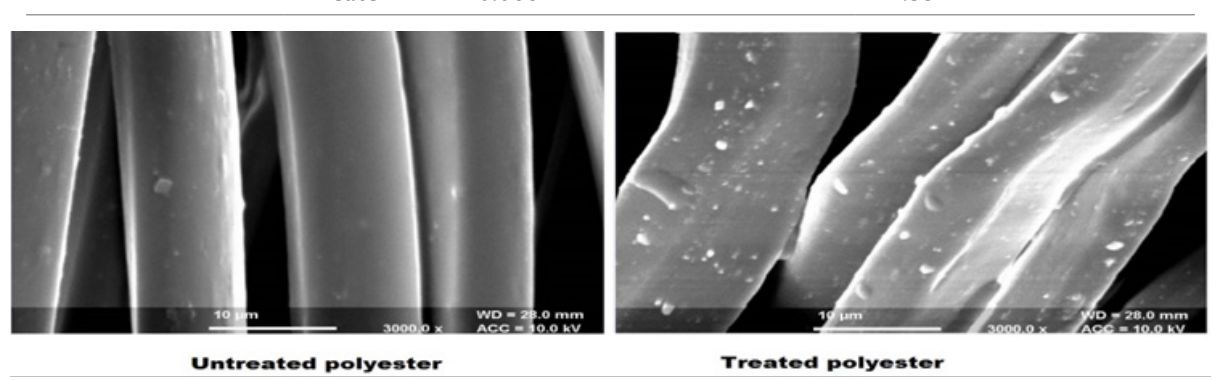

Figure 4 SEM images of untreated and treated polyester antimicrobial finish (sample SI).

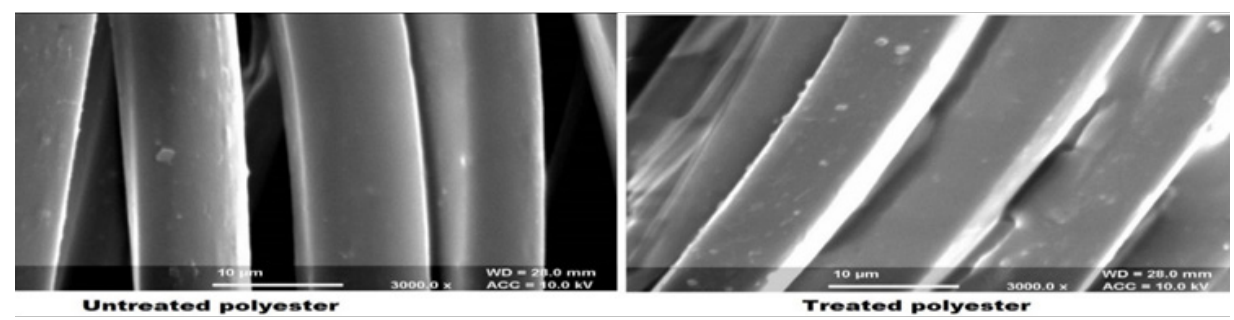

Figure 5 SEM images of untreated and treated micro polyester antimicrobial finish (sample SI).

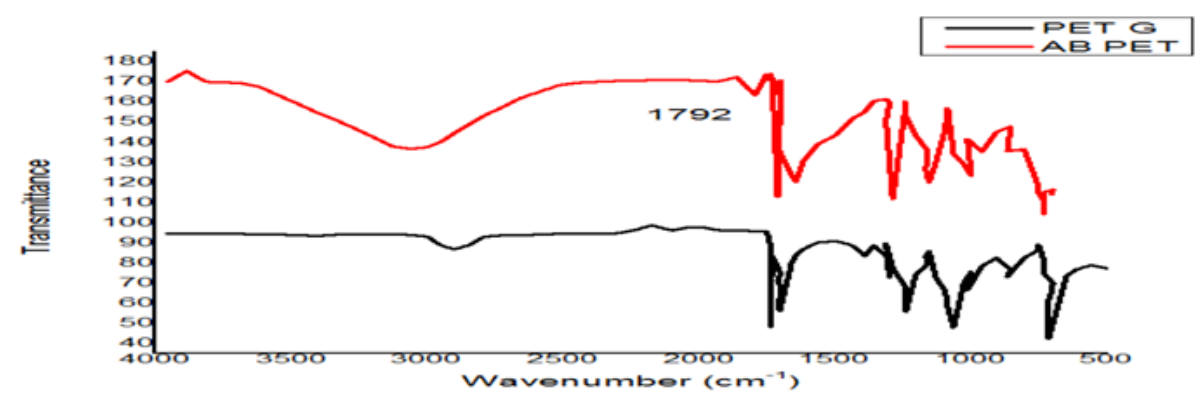

Figure 6 FTIR spectrum of untreated and treated polyester knitted masks fabrics antimicrobial finish. 


\section{Moisture management finishes}

Shown the Figures 7-9, FTIR spectra of all the polyester fabrics treated as well as untreated. There were some characteristic peaks of the functional group which could explain the presence of Moisture
Management finish on the polyester fabric. The peak $1138 \mathrm{~cm}^{-1}$ given importance (Si-o-Si), $1094 \mathrm{C}-\mathrm{O}$ (stretch bond). This peak indicates the presence of Moisture Management finish on knitted polyester\& Micro Polyester masks samples.

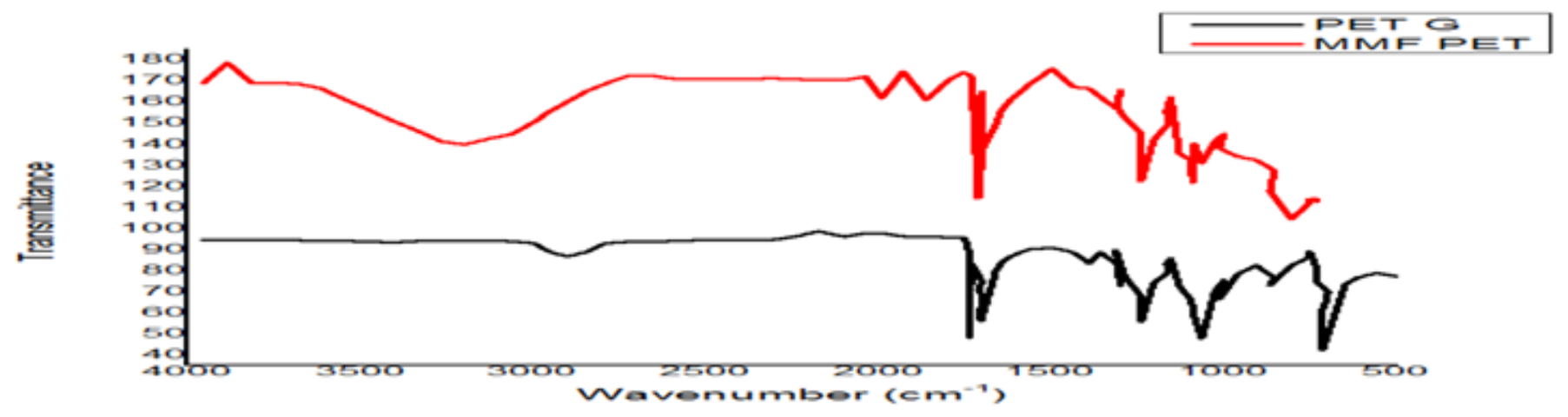

Figure 7 FTIR spectrum of untreated and treated polyester knitted fabrics moisture management finish (sample SI).

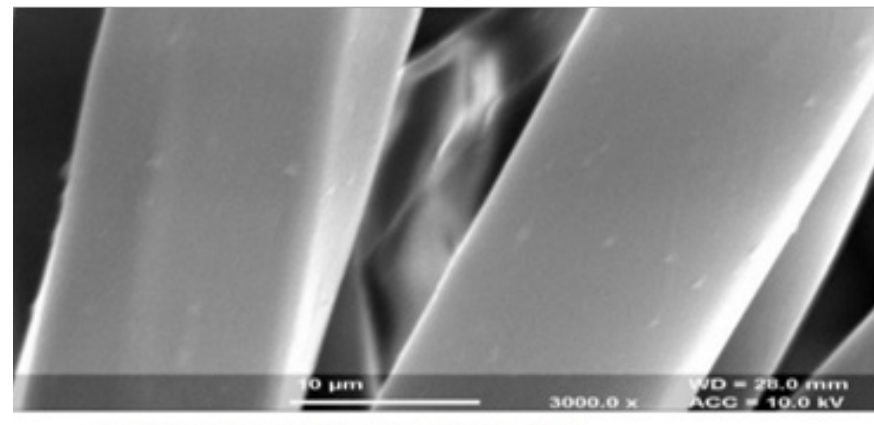

Untreated Micro polyester

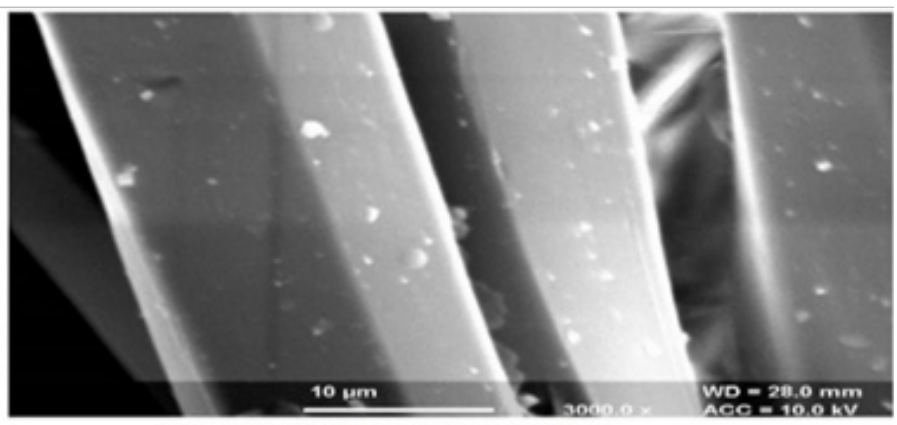

Treated Micro polyester

Figure 8 SEM images of untreated and treated polyester moisture management finish.

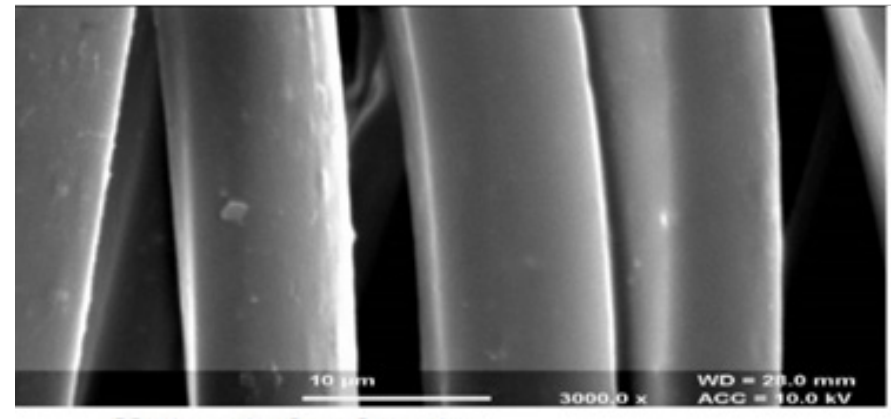

Untroated polyester

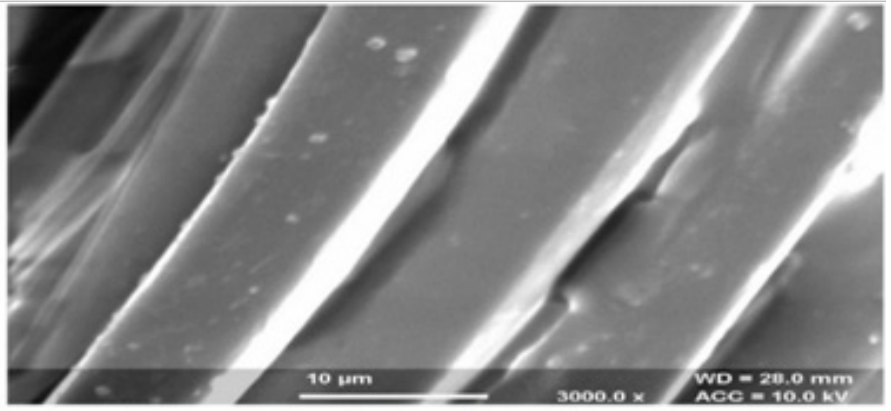

Treated polyester

Figure 9 SEM images of untreated and treated micro polyester moisture management finish.

\section{Vertical wicking measurement}

In case of vertical wicking, the contribution percentage of finish type is higher; but it is influencing only till $10 \mathrm{~min}$. The vertical wicking of micro polyester fabric is faster in each case. ${ }^{14,15}$ But as we move from micro polyester to texturized polyester, due to decrease in density of capillary channels, vertical wicking process is slower and water rise happened significantly faster only up to $10 \mathrm{mins}$.
The According to result (Table 5) and Figures 10-13, the moisture management finish has a very significant influence on all the two fabric types. There is increase in vertical wicking of samples finished with moisture management and antimicrobial finish is further enhanced after washing. This reusable for the three-layer surgical mask sample. This study also stated that after fifteen times laundering cycle there is increase in the value of all measured comfort and antimicrobial properties as shown SEM image Figure 14. 
Table 5 Result vertical wicking

\begin{tabular}{|c|c|c|c|c|c|c|}
\hline \multirow{2}{*}{ Fabric type } & \multirow{2}{*}{\multicolumn{2}{|c|}{ Fabric parameters }} & & \multicolumn{3}{|c|}{ Vertical wicking height $(\mathrm{cm})$, Wales direction } \\
\hline & & & & $5 \mathrm{~min}$. & $10 \mathrm{~min}$. & 15 min. \\
\hline & & Without & & 9.65 & 11.32 & 12.4 \\
\hline & & & Mean & $13.25 \pm 5.02$ & $13.86 \pm 3.98$ & $14.02 \pm 5.2$ \\
\hline & & Before wash & & & & \\
\hline & MMF Finish & & S.D & 3.37 & 2.72 & 4.37 \\
\hline & & & Mean & $15 \pm 4.88$ & $14.24 \pm 4.35$ & $|4.3| \pm 6.14$ \\
\hline & & After 15 washes & & & & \\
\hline \multirow[t]{14}{*}{ Mirco Polyester } & & & S.D & 2.77 & 2.66 & 4.49 \\
\hline & & & Mean & $10.69 \pm 2.52$ & $12.11 \pm 3.94$ & $11.58 \pm 5.7$ \\
\hline & & Before wash & & & & \\
\hline & & & S.D & 2.07 & 3 & 4.67 \\
\hline & AM Finish & & & & & \\
\hline & & & Mean & $11.02 \pm 2.85$ & $12.21 \pm 3.33$ & || $.7 \mid \pm 5.83$ \\
\hline & & After 15 washes & & & & \\
\hline & & & S.D & 2.16 & 2.88 & 4.64 \\
\hline & & Without & & 9.5 & 10.8 & 11.83 \\
\hline & & & Mean & $11.79 \pm 2.37$ & $12.92 \pm 3.46$ & $12.92 \pm 4.37$ \\
\hline & & Before wash & & & & \\
\hline & MMF Finish & & S.D & 3.2 & 3.78 & 3.57 \\
\hline & & & Mean & $12.29 \pm 2.84$ & $13.04 \pm 3.59$ & $13.13 \pm 4.58$ \\
\hline & & After 15 washes & & & & \\
\hline \multirow[t]{8}{*}{ Polyester } & & & S.D & 3.86 & 3.94 & 3.72 \\
\hline & & & Mean & $9.7 I \pm 3.63$ & $10.34 \pm 4.25$ & $11.16 \pm 5.62$ \\
\hline & & Before wash & & & & \\
\hline & & & S.D & 3.9 & 3.2 & 2.55 \\
\hline & AM Finish & & & & & \\
\hline & & & Mean & $9.93 \pm 3.84$ & $10.4 \pm 4.33$ & II. $38 \pm 5.83$ \\
\hline & & After 15 washes & & & & \\
\hline & & & S.D & 3.79 & 3.13 & 2.59 \\
\hline
\end{tabular}

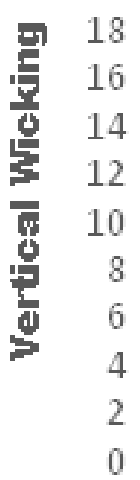

\section{Time (min.)}

Figure 10 Vertical wicking of the micro polyester fabric with moisture management finish. 


\title{
Micro Polyester with Antimicrobial Finish (AMF) Treatment
}

\author{
- Micro PET Without Mirco PET AM Before wash $\square$ Mirco PET AM after 15 wash
}

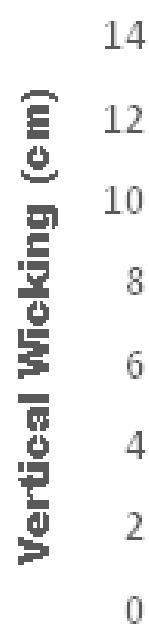
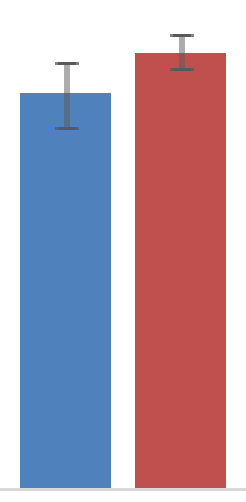

5 min.
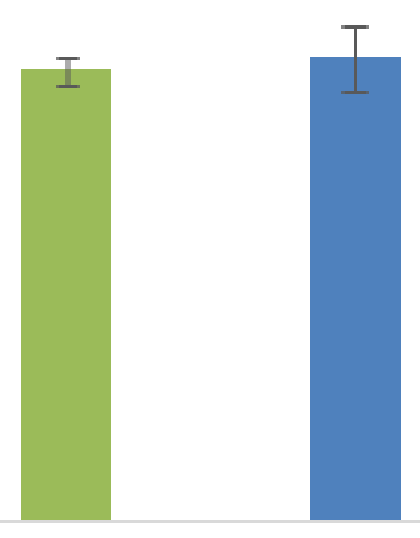

$10 \mathrm{~min}$
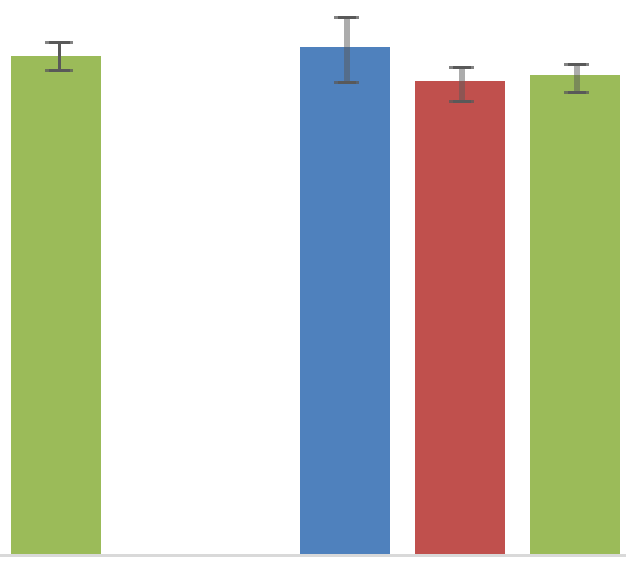

15 min.

\section{Time (min.)}

Figure I I Vertical wicking of the micro polyester fabric with antimicrobial finish.

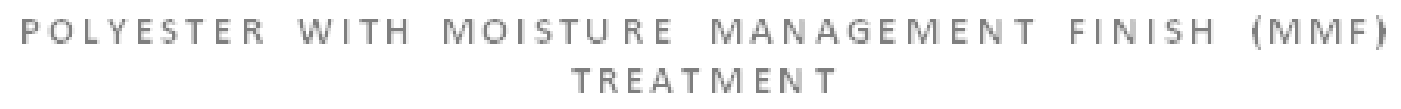

를 PET Without 를 PETMMF Beforewash 를 PET MMF after 15 wash

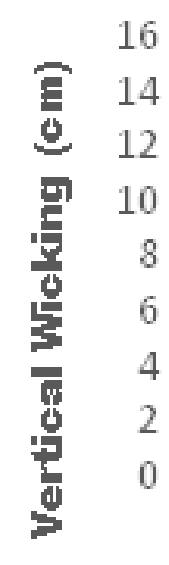

16 4

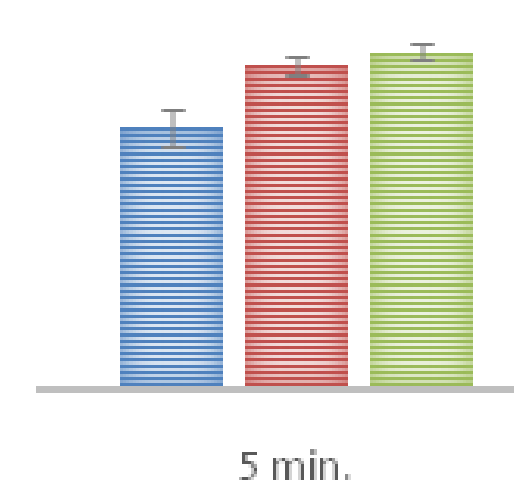

$$
5 \text { min. }
$$

$10 \mathrm{~min}$

\begin{abstract}
$15 \mathrm{~min}$.
\end{abstract}

\section{Time (min.)}

Figure 12 Vertical wicking of the polyester fabric with moisture management finish. 


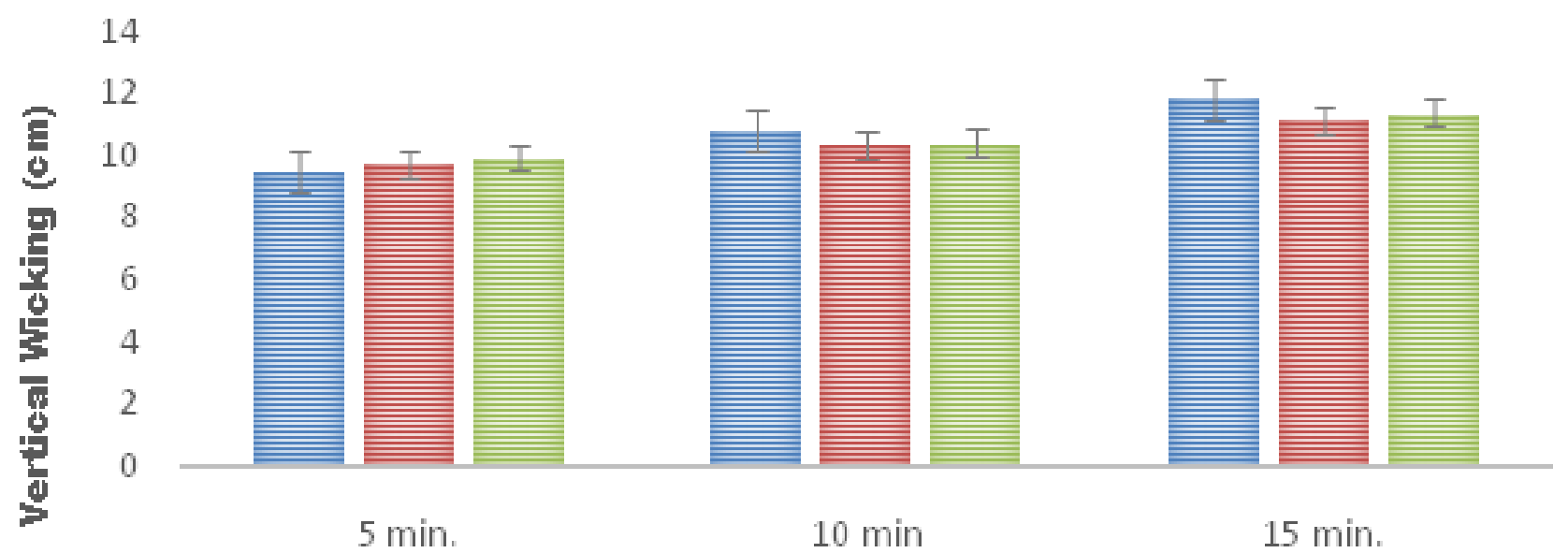

\section{Time (min.)}

Figure I 3 Vertical wicking of the polyester fabric with antimicrobial finish.

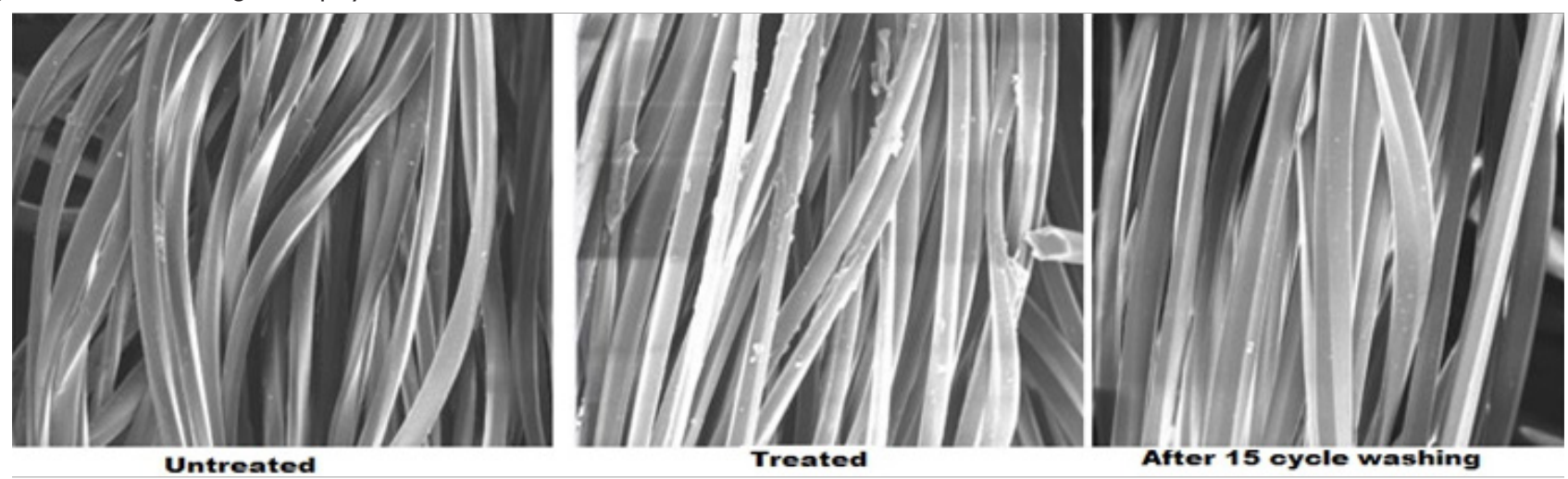

Figure I 4 SEM images of untreated, treated and after I5 washing cycle polyester finishes.

According to the results specification parameters shown in Table 6 and Table 7, it is all good and better performance face mask knitted. The hydraulics of the pores is formed by the channel in which the fibres are farthest apart. Such a pore has many bends. The air velocity of inhalation and exhalation is relatively small (with the exception of sneezing) and the flow of air through the mask is laminar. In laminar flow, the air flow changes slightly when it comes in close proximity to the fibre surface. Small particles, such as viruses, can be thrown out of the toxin or move according to Brown's law. In addition, airflows completely change the direction of the inhalation and exhalation rhythm, which also helps to increase filtration efficiency. The masks are tested for filtration efficiency. Certain variations in quality may occur as a result of a poorly managed production process. Porosity may be too high (reduced filtration efficiency) or too low (shortness of breath).

Table 6 Result specification parameters for face mask

\begin{tabular}{llll}
\hline Type of masks & $\begin{array}{l}\text { Three Layer fabric with } \\
\text { Air permeability }(\mathbf{c m} 3 / \mathbf{s e c} / \\
\mathbf{c m} 2)\end{array}$ & $\begin{array}{l}\text { Three Layer fabric } \\
\text { with Average Pore } \\
\text { diameter }(\mu \mathrm{m})\end{array}$ & $\begin{array}{l}\text { Three Layer fabrics } \\
\text { with filtration } \\
\text { efficiency }(\%)\end{array}$ \\
\hline $\begin{array}{l}\text { Reusable Knitted Face } \\
\text { Mask }\end{array}$ & 31.26 & 22.31 & $\begin{array}{l}\text { Three Layer fabric } \\
\text { with thickness } \\
(\mathbf{m m})\end{array}$ \\
\hline
\end{tabular}


Table 7 Result specification porosity parameters of face masks

\begin{tabular}{lllll}
\hline Fabric & $\begin{array}{l}\text { Average hydraulic pore } \\
\text { dia. micrometers }\end{array}$ & $\begin{array}{l}\text { Maximum pore dia. } \\
\text { micrometers }\end{array}$ & $\begin{array}{l}\text { Open } \\
\text { surface }(\%)\end{array}$ & $\begin{array}{l}\text { No. of Pores } \\
\text { per }\left(\mathbf{I} \mathbf{c m}^{2}\right)\end{array}$ \\
\hline Reusable Knitted Face Mask & 66.74 & 124.07 & 13.1 & 7.63 \\
\hline
\end{tabular}

\section{Conclusion}

This will surgical mask beneficially for the user of village people, small town and communities, at home and at health care facilities in areas. It will help to prevent covid 2019 virus infection. It is able to anti-dust pollution, washable \& reusable product. It is faster sweat absorption and provides disease protection, relief from bad odours and more for ultimate best performance by face masks.

The followings conclusions are derived from the above experimental work and given below:

a. It is finally observed that the antimicrobial properties of polyester, micro polyester fabrics got improved with the Quatarnery ammonium compound in antimicrobial finish.

b. It is finally observed that the soft \& comfort properties of polyester, micro polyester fabrics got improved with the Hydrophilic silicone softener in moisture management finish.

c. SEM images at the uniform coating of the polyester fabrics with a particle size ranging $10 \mathrm{~nm}$. The similar trend is also found for the micro polyester.

d. The impregnation of finishes coating on polyester knitted fabrics was also confirmed by FTIR spectroscopy.

e. Finally, it is concluded that functional finishing chemicals as found non-toxic can be useful for the face masks knitted fabric, finishing for improving its functional performance.

\section{Acknowledgments}

I am Thankful to the MRSPTU Campus and all staff of textile engineering department of Giani Zail Singh Campus College of engineering and technology for their support to carry out this research work.

\section{Funding}

None.

\section{Conflicts of interest}

The authors declare there are no conflicts of interest.

\section{References}

1. Tang JW, Nicolle AD, Pantelic J, et al. Qualitative real-time schlieren and shadowgraph imaging of human exhaled airflows: an aid to aerosol infection control. PLoS One. 2011;6(6):1-6.
2. Tang JW, Settles G. Images in clinical medicine. Coughing and masks. $N$ Engl J Med. 2009;1(2):361-362.

3. Wen Z, Yu L, Yang W, et al. Assessment the protection performance of different level personal respiratory protection masks against viral aerosol. Aerobiologia. 2013;29(2):365-372

4. Stelzer-Braid S, Oliver BG, Blazey AJ, et al. Exhalation of respiratory viruses by breathing, coughing, and talking. J Med Virol. 2009;81(1):1674 1679.

5. Morawska L. Droplet fate in indoor environments, or can we prevent the spread of infection? Indoor Air. 2006;16(1):335-347.

6. Doust BC, Lyon AB. Face masks in infections of the respiratory tract. $J$ Amer Med Assoc Chicago. 1918;911(15):1216-1219.

7. Belkin NL. The surgical mask has its first performance standard a century after it was introduced. Bull Amer College Surgeons. 2009;94(12):22-25.

8. Woodhead K, Taylor EW, Bannister GC, et al. Behaviours and rituals in the operating theatre a report from the hospital infection society working party on infection control in operating theatres. J Hosp Infect. 2002;51(4):241-255.

9. Hasieh YL. Liquid transport in fabric structures. Textile Research Journal. 1995;65(5):299-307.

10. Nadige GV, Shukla Sanjeev R. Antibacterial properties of silk fabric treated with silver nanoparticles. Journal of textile institute. 2016;107(12):15431553.

11. Yadav A, Prasad V, Kathe AA, et al. Functional finishing in cotton fabrics using zinc oxide nanoparticles. Bulletin of materials science. 2006;29(6):641-645.

12. Mohammed Z, Mohammed QR, Eddine SL, et al. Phenolic content, antioxidant and antibacterial activities of peel extract from Punica Granatum L. Research journal of chemistry and environment. 2018;22(4):9-15.

13. Klemencic D, Tomsic B, Kovac F, et al. Antimicrobial cotton fibres prepared by in situ synthesis of $\mathrm{AgCl}$ into a silica matrix. Cellulose. 2012;19(5):1715-1729.

14. Oner E, Okur A. The effect of different knitted fabrics structures on the moisture transport properties. Journal of the textile institute. 2010;104(11):1164-1177.

15. Chen Q, Maggie T, Ka-Po, et al. Thermo physiological comfort properties of polyester weft knitted fabrics for sports T-shirt. Journal of the textile institute. 2017;108(8):1421-1429. 